\title{
Ассоциация с возрастом ДНК-маркеров генов «фармакологического ответа» в этнической группе абхазов
}

\author{
Эрдман В. В.', Насибуллин Т. Р.', Туктарова И. А.', Тимашева Я. Р.1, \\ Матуа А. 3.', Викторова Т. В. ${ }^{3}$ \\ 1 - ФГБНУ Уфимский федеральный исследовательский центр Российской академии наук, Россия, Уфра \\ ² - Научно-исследовательский институт экспериментальной патологии и терапии АНА, Абхазия, Сухум \\ з - ФГБОУ ВО «Башкирский государственный медицинский университет» МЗ РФ, Россия, Уфра
}

Ключевые слова: этническая группа; абхазы; долголетие; ген фармакологического ответа; CYP1A2; PON1

Для цитирования:

Эрдман В.В., Насибуллин Т.Р., Туктарова И.А., Тимашева Я.Р., Матуа А.З., Викторова Т.В. Ассоциация с возрастом ДНК-маркеров генов «фармакологического ответа» в этнической группе абхазов // Фармакогенетика и фармакогеномика. 2020;(2):24-25. (In Russ). DOI: 10.37489/2588-0527-2020-2-24-25

Введение. Известно, что один и тот же лекарственный препарат по-разному воздействует на организм разных пациентов. Ключевым эндогенным фактором индивидуального фармакологического ответа является генетическая конституция [1]. Структурные особенности генов ферментов, принимающих участие в метаболизме лекарственных средств (ЛС), отвечают за широкую вариабельность возможных реакций организма на лечение. Учитывая генетическую гетерогенность популяций человека, актуальной задачей фармакогенетики является выявление возможных этноспецифических ДНК-маркеров генов чувствительности к фармакологическим препаратам [2]. Кроме того, риск развития побочных нежелательных эффектов ЛС увеличивается среди лиц пожилого и старческого возраста. Стареющий организм особенно предрасположен к заболеваниям, что закономерно влечёт за собой увеличение количества используемых ЛС и, как следствие, возрастание частоты неблагоприятных реакций на их применение. Изменяющийся с возрастом гормональный и иммунный статус организма также оказывает влияние на функционирование генов, что, в свою очередь, необходимо учитывать при терапии лиц разного возраста. Принимая во внимание полиморбидный статус пациентов преклонного возраста, важно исследовать множественные эффекты сочетанного влияния фармакологических препаратов. Молекулярно-генетической основой при этом может выступать индивидуальный характер межгенных взаимодействий.

Цель. Выявление комплексных фармакогенетических маркеров у лиц преклонного возраста на основе анализа ассоциаций функциональных полиморфных локусов 12 генов «фармакологического ответа»: $A B C B$ (rs1045642), AKT1 (rs3803304), CYP1A2 (rs762551), CYP2C19 (rs4244285), CYP2D6 (rs3892097), CYP3A5 (rs776746), CYP3A4 (rs2740574), HIF1A (rs11549465), MTHFR (rs1801133), NAT2 (rs1208), PON1 (rs662), NFE2L2 (rs6721961) с возрастом в этнической группе абхазов.

Материалы и методы. Для проведения исследования сформирована группа, включающая 273 здоровых мужчин и женщин, не родственных между собой, коренных жителей Абхазии. Вся выборка лиц в возрасте от 20 до 105 лет включает индивидов среднего (20-59 лет), пожилого (60-74 года), старческого (75-89 лет) возраста и долгожителей (90-105 лет). Аллельные варианты генов идентифицированы методами аллель-специфичной ПЦР и ПЦР в реальном времени (ПЦР-РВ) с использованием TaqMan-зондов. Результаты исследования проанализированы в программах GENEPOP, SPSS (v. 21.0), APSampler (v.3.6.1.). Сравнение групп индивидов разного возраста по частотам генотипов и аллелей по каждому полиморфному ДНК-маркеру выполнено с помощью точного критерия Фишера, для обработки полигенных данных - методом МонтеКарло Марковскими цепями (МСМС) [3].

Результаты. При однолокусном анализе ассоциаций установлены генетические маркеры, значимые для возраста долголетия в этнически однородной группе абхазов, по генам CYP1A2 и PON1. Наблюдается снижение частоты «мутантного» аллеля CYP1A2*A и возрастание частоты «дикого» аллеля $C Y P 1 A 2^{*} \mathrm{C}$ среди долгожителей $(41,67$ и $58,33 \%$, 
соответственно) относительно таковых в группах лиц среднего (61,62 и 38,38 \%), пожилого $(59,68$ и $40,32 \%)$ и старческого возраста $(63,39$ и 36,61\%), $(p>0,01)$. Соответствующие различия характерны для гомозиготных генотипов: в возрасте 90 лет и старше практически в два раза возрастает частота генотипа $C Y P 1 A 2^{*} \mathrm{C} / \mathrm{C}(p>0,05)$ и снижается частота генотипа $C Y P 1 A 2 * \mathrm{~A} / \mathrm{A}(p>0,01)$. Сходная картина наблюдается и для полиморфного локуса гена PON1: в группе долгожителей статистически значимо снижена частота аллеля $P O N 1^{*} \mathrm{~A}$ и генотипа $P O N 1^{*} \mathrm{~A} / \mathrm{A}$ и повышена частота аллеля $P O N 1^{*} \mathrm{G}$ и генотипа $P O N 1^{*} \mathrm{G} / \mathrm{G}(p>0,01)$. Аллель $P O N 1^{*} 662^{*} \mathrm{G}$, для которого установлено повышение частоты среди долгожителей, ассоциирован с усилением активности параоксоназы 1 по отношению к ксенобиотикам.

Мультилокусный анализ позволил выявить 14 паттернов, включающих полиморфные маркеры генов $A B C B, A K T 1, C Y P 1 A 2, H I F 1 A, P O N 1$ и NFE2L2 в разных комбинациях, показывающих ассоциацию с возрастом старше 60 лет при уровне значимости $p>0,05$. Формирующими компонентами комплексных ДНК-маркеров генов «фармакологического ответа», для которых установлено по- вышение частоты с возрастом, является сочетание CYP1A2*C + PON1*G+NFE2L2*T $(15,54 \%$ в старческой группе против 3,05\% в группе лиц среднего возраста, $\mathrm{OR}=5,95 ; p=0,0009)$. Среди лиц старше 60 лет установлено снижение шансов обнаружения шести паттернов, в составе которых наиболее частыми элементами являются аллели $A B C B^{*} \mathrm{~T}, P O N 1^{*} \mathrm{~A}$ и генотип NFE2L2*G/G $(36,97 \%$ против $53,54 \%$ в группе лиц среднего возраста, $\mathrm{OR}=0,51 ; P=0,007)$.

Выводы. С долголетием в этнической группе абхазов ассоциированы аллели $C Y P 1 A 2^{*} \mathrm{C}, P O N 1^{*} \mathrm{G}$, NFE2L2*T и генотипы CYP1A2* C/C, PON1*G/G. Возможно, что выживаемость и достижение возраста долголетия является, в частности, следствием носительства аллелей, которые обеспечивают более эффективный метаболизм ксенобиотиков, в том числе ЛС. Таким образом, подтверждается важность прогнозирования эффективности применения ЛС с учётом генетической конституции пациента и коррекцией на его возраст и этническую принадлежность.

Исследование выполнено при финансовой поддержке РФФИ и АНА в рамках научного проекта № 19-5440007.

\section{Литература / References}

1. Wilke RA, Dolan ME. Genetics and variable drug response. JAMA. 2011;306(3):306-307. DOI: 10.1001/jama.2011.998.

2. Holmes MV, Shah T, Vickery $\mathrm{C}$ et al. Fulfilling the promise of personalized medicine? Systematic review and field synopsis of pharmacogenetic studies. PLoS One. 2009;4(12):e7960. DOI: 10.1371/ journal.pone.0007960.

3. Favorov AV, Andreewski TV, Sudomoina MA et al. A Markov chain Monte Carlo technique for identification of combinations of allelic variants underlying complex diseases in humans. Genetics. 2005;171(4):2113-2121. DOI: $10.1534 /$ genetics. 105.048090 